\title{
A LCEDO C丑RULEA.
}

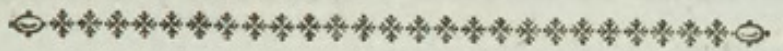

\section{CHARACTER GENERICUS.}

Roftrum trigonum, craffum, rectum, longum. Lingua carnofa, breviffima, plana, acuta. Pedes grefforii plerifque.

$$
\text { Lin. Syft. Nat. p. } 178 .
$$

CHARACTER SPECIFICUS, EंC.

ALCEDO CÆRULEA, fubtus rufa, humeris uropygioque viridibus, fuperciliis et torque albis.

ALCEDO CÆRULEA, fubtus rufa, fuperciliis et torque albis.

$$
\text { Lin. Syft. Nat. Gmel. p. 454. }
$$

\section{ALCEDO C⿸尸RULEA.}

$$
\text { Lath. ind. orn. p. } 249 .
$$

ISPIDA INDICA torquata.

$$
\text { Brifs. 4. p. } 481 \text {.t. 37. f. 2. A. }
$$

In India innafcitur Alcedo cærulea, Alcedinem Europæam feu Ifpidam magnitudine fuperans : caput $\mathrm{E}$ dorfum- 
dorfumque veftiunt pennæ cæruleæ fplendidifimæ; alarum tectrices minores uropygiumque pulchre virent; pectus et abdomen rufefcunt; roftrum pedesque nigricant. 
$\therefore$

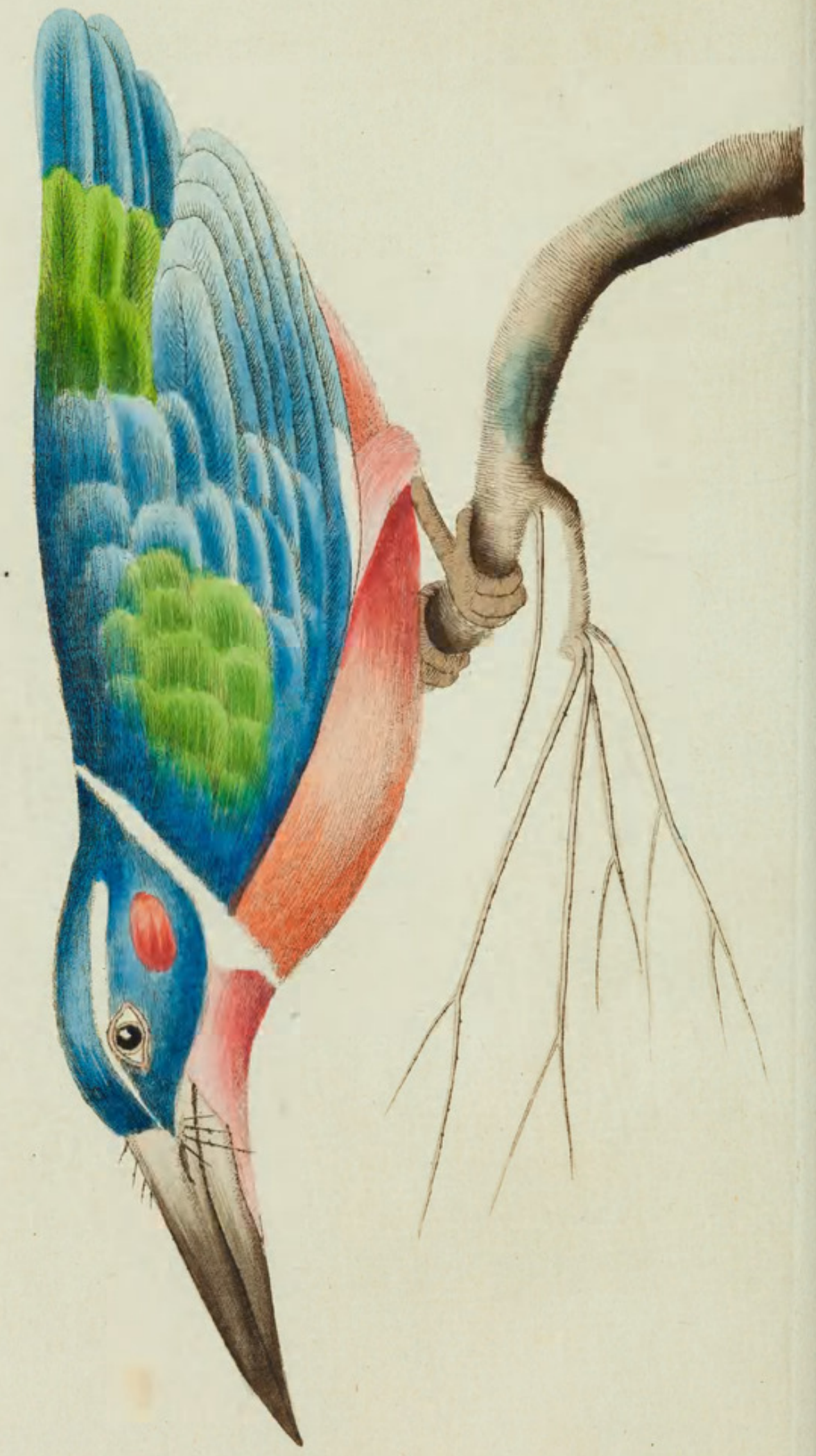




\section{WHITE-COLLARED KINGFISHER.}

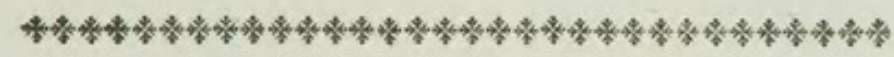

\section{GENERIC CHARACTER.}

Bill trigonal, thick, ftrait, long, fharp-pointed. Tongue flefhy, very fhort, flat, fharp-pointed. Feet (in moft fpecies) grefforial.

\section{SPECIFIC CHARACTER, EंC.}

BLUE KINGFISHER, rufous beneath, with green fhoulders and rump, a white collar round the neck, and a white ftreak over the eyes.

\section{WHITE-COLLARED KINGFISHER.}

$$
\text { Lath. Jyn. p. } 620 .
$$

The white-collared Kingfifher is a native of India: in fize it exceeds the common or European Kingfifher: the head and back are of a rich and beautiful blue: the fhoulder-feathers or fmaller wing-coverts and the rump of a bright green : the breaft and abdomen rufous; the bill and feet dufky.

$\mathrm{E}_{2}$ 


\section{$2 \mathrm{BHL}$ Biodiversity Heritage Library}

Shaw, George. 1796. "The White-Collared Kingfisher, Alcedo cærulea [PI. 269]." The Naturalist's Miscellany 8(LXXXV), https://doi.org/10.5962/p.310812.

View This Item Online: https://www.biodiversitylibrary.org/item/276320

DOI: https://doi.org/10.5962/p.310812

Permalink: https://www.biodiversitylibrary.org/partpdf/310812

\section{Holding Institution}

Museums Victoria

\section{Sponsored by}

Atlas of Living Australia

\section{Copyright \& Reuse}

Copyright Status: Public domain. The BHL considers that this work is no longer under copyright protection.

This document was created from content at the Biodiversity Heritage Library, the world's largest open access digital library for biodiversity literature and archives. Visit BHL at https://www.biodiversitylibrary.org. 